\title{
The Improvement of the Service Quality of The Syariah Bank in Facing The Global Competition
}

\author{
Estik Hari Prastiwi \\ Doctoral Student of Brawijaya University
}

Ujianto

Lecturer of Economics Faculty at University of 17 Agustus 1945 Surabaya

This study aims to examine the service quality of Islamic bank in the BPRS Syariah Jabal Nur Surabaya. By using 6 dimensions of Carter method including Compliance, Assurance, Reliability, Tangibles, Empathy, and Responsiveness, this study found that Tangible is the only dimension that influences positively to the customer satisfaction. While the other dimensions fail to increase to the customer satisfaction. To measure the customer satisfaction, this study compared the perception of the customer with the expectation of the customer.This study then suggests that the sequence of quality of service needs to be improved is Compliance, Assurance, Responsiveness, Empathy, and Reliability.

Key Words: Quality of Service, Carter Method, Customer Perception, Customer Expectations, Satisfaction

\section{Introduction}

In the era of globalization, only products and services that have competitive advantages can compete and survive. Many foreign banks enter Indonesia and compete with national banks. Besides conventional banks, many sharia banks establish and have different market segments. Sharia economic system has an advantage that is not owned by conventional banks because in Islamic economic does not simply considers aspects of economy but also aspects of humanity, religion social and politic. Sharia banks in providing services to the community should always follow the society development. With the demands of the development and improvement of service quality an Islamic bank can not assume that complaints and suggestions system can describe the complete satisfaction and disappointment of customers as a benchmark of the quality of a banking product. Most customers move to another finance institution if the received service is not satisfactory than filing a complaint. Sharia Banks must always be responsive in measuring behavioral

\author{
M Sihab Ridwan \\ Lecturer of Economics Faculty at University \\ of 17 Agustus 1945 Surabaya \\ Lpdp \\ Funding Institution \\ Email : estikhariprastiwi@yahoo.co.id
}

development preferences and developments of customer perceptions by conducting regular surveys. Muslim standard model of service quality dimensions of sharia banking (2008) should consist of six dimensions and determinants of good satisfaction. The relationship between service quality and customer satisfaction is very significant. Customer perception failed to meet their expectations of the quality of sharia bank services in Malaysia (Rofikul, 2015). Moez (2016) said the factors that affect the selection of Syariah banks in Tunisia are service quality, trust, and compliance with sharia law.

Quality of service are centered on efforts to meet the needs and desires of consumers and accuracy of delivery to compensate for customer expectations. Consumer satisfaction or dissatisfaction is the difference between perceived expectations and perceived performance. If the service is perceived as expected the quality of service is good and satisfactory. If the service received exceeds customer expectations then quality can be categorized as ideal quality. Conversely if the service received is lower than expected then the quality of service is low. Assessment of the quality of service depends on the ability of Islamic Banks to meet customer expectations consistently.

BPR Syariah is one form of BPR whose management must be based on sharia principles and focused on serving micro and small enterprises (UMK) who want easy process, fast service, and light requirements. BPR Syariah has officers who serve as a fleet pickup deposit and withdrawal savings / deposits including installment of financing installments. This service is very relevant to the needs of the community of UMK who tend not to improve their daily activities at home / shop / market. The problem in this research is whether the quality of BPR Syariah service has satisfied the consumers? 


\section{THEORETICAL REVIEW}

Service qualiity dimension according to Parasuraman is the comparison between perceived service and Expected service of consumer (Purnama, 2006). If the quality of service is felt the same or exceeds the quality of service expected then the service is said to be qualified and satisfactory. Othman and Owen offer CARTER dimensions to measure the quality of service of Islamic bank including Compliance, Assurance, Reliability, Tangibles, Empaty, and Responsiveness (Purnama, 2006). Quality Measurement Method of service Carter method of service quality measurement uses gap model developed by Parasuraman et al (Purnama 2006). Service quality is a function of the gap between consumers' expectation of service and their perception of actual service generated by the company. The consumer's expectation of service quality is the desire or the ideal consumer demand for the service to be provided by the service provider. While the consumer perception is the consumer's assessment of services that have been felt or obtained. Quality of service is the difference between perceived service or perceived consumer (perception) with the ideal service desired or requested consumer (hope).

\section{Previous Research}

1. Research was conducted by Karjadi Mintaroem (Journal Ihya "Ulum al-Din 2004) under the title "Service Quality and Customer Satisfaction of Islamic Banking in Surabaya" which examined 80 Bank Islam customers in Surabaya randomly in December 2003. However, only 52 respondents can be processed by using statistical analysis. The method used is Carter dimension which uses 6 dimension of quality, they are: Compliance, Assurance, Reliability, Tangible, Empaty, and Responsiveness. The result of this research is the dimension of Reability, Assurance, and Responsiveness is more important dimension than Compliance Tangible and Empaty.

2. The research conducted by Sharil Shafie, Dr. Wan Nursofiza Wan Azmi and Prof. Sudin Harun (2004) say that researching the customers of Bank Islam Malaysia Berhad with CARTER model covers Compliance, Assurance, Reliability, Tangible, Empaty, and Responsiveness by using 35 question items. The results obtained in the order of the highest to the lowest considered important for Customers are Compliance, Reliability, Assurance, Responsiveness, Empaty, and Tangible.

3. Research conducted by Erlane K Ghani and Jamaliah (2011) maintain that to examine the use of CARTER method in 25 institutions of Zakat in Malaysia with Delphy method obtained 11 important attribute,s in tangibles dimension. 10 attributes are important in Empathy dimensions, 10 attributes are important in the dimensions of Responsiveness, 11 attributes are important in the dimensions Reliability / Assurance, and 15 attributes are important in the dimensions Compliance

4. Muslim Amin and Zaidi Isa (2008) use a SEM approach to see the relationship between customer satisfaction of six dimensions of service quality (CARTER model) in Islamic banks of Pakistan, UK and UAE. Using 6 dimensions of quality and customer of Moslem and non Muslim shows that customer of Islamic banking of Pakistan and UK consider that assurance, reliability, and empathy are significant factor for customer satisfaction. While UAE Customers consider the assurance and tangible as a significant dimension of satisfaction

5. Asma Abdul Rehman study (2012) using 6 dimensions of quality with the respondents of Muslim and non Muslim customers found that relationship of service quality and customer satisfaction is very significant.

6. The study of Rafikul Islam, Selim Ahmed, Dzuljastri Abdul Razak, (2015) using 6 dimensions of service quality showed that customer perception failed to meet customers expectation on the quality of sharia bank services in Malaysia.

\section{RESEARCH METHODOLOGY}

This research uses survey method and the amount of respondents used in this study is 100 respondents (customer) in BPRS. The study was conducted from May to September 2015. The Measurement was established through a Likert scale ranging from "1" as Strongly Disagree to "5" as Strongly Agree. The purpose of this study is to look at the gap between Expected service (ES) and Perceived service (PS) where Perceived Serviced Quality is show

1. Expectation exceeded ES < PS (Quality Surprises)

2. Expectations met $\mathrm{ES}=\mathrm{PS}$ (Satisfactory Quality)

3. Expectations not met ES > PS (Unacceptable)

Quality services measured with six quality dimensions include

1. Compliance variables are Islamic principles and laws that have been implemented with indicators running Islamic sharia no interest for savings time deposits or financing revenue sharing for savings time deposits and financing.

2. Assurance Variables is the ability and skills of employees in providing good service with indicators employees are polite and friendly understand all products BPRS have extensive knowledge

3. Reliability Variable is the ability to provide services with immediate accurate and satisfactory with indicators ensure security in 
transactions fast in processing financing service time on time.

4. Tangible variables are physical appearance and equipment with indicator office display in comfortable and air conditioned lounge special room for special customer free drink reading and TV for entertainment.

5. Empaty Variable is able to establish communication relationships and understand the needs of customers with indicators ensuring the confidentiality of customer data simplify procedures for financing profit sharing provided attractive and appropriate agreement.

6. Responsiveness Variablebis the ability of employees to assist customers and responsive in providing services with indicators serve the Islamic help customer difficulties serve quickly and efficiently.

7. The variable of customer satisfaction is the result (outcome) perceived on the use of products and services the same or exceed the desired expectations

\section{DISCUSSION}

Customer rating to the quality of service of BRP Syariah Jabal Nur Surabaya

Table 1: Customer rating on the quality of service of BPR Syariah in Surabaya.

\begin{tabular}{|c|c|c|c|c|}
\hline Demention & $\begin{array}{c}\text { Average } \\
\text { Expected }\end{array}$ & $\begin{array}{c}\text { Avareage } \\
\text { perceived }\end{array}$ & Gap & Conclusition \\
\hline Compliance & 4.17 & 3.72 & -0.45 & $\begin{array}{c}\text { Not } \\
\text { satisfaction }\end{array}$ \\
\hline Assurance & 4.29 & 4.06 & -0.23 & $\begin{array}{c}\text { Not } \\
\text { satisfaction }\end{array}$ \\
\hline Reliability & 4.2 & 4.11 & -0.09 & $\begin{array}{c}\text { Not } \\
\text { Satisfaction }\end{array}$ \\
\hline Tangible & 3.98 & 3.98 & 0 & Satisfaction \\
\hline Empaty & 4.22 & 4.08 & -0.14 & $\begin{array}{c}\text { Not } \\
\text { Satisfaction }\end{array}$ \\
\hline $\begin{array}{c}\text { Responsiven } \\
\text { ess }\end{array}$ & 4.21 & 4.05 & -0.16 & $\begin{array}{c}\text { Not } \\
\text { satisfaction }\end{array}$ \\
\hline
\end{tabular}

- Customer evaluation on Compliance dimension is not satisfactory perception (service received and perceived) and not in accordance with customer's expectation. BPRS is still not fully implemented to Islamic Shariah where most financing are still in the form of sale and purchase while financing for project of agriculture and plantation still left behind.

- Assessment of customer to Assurance dimension is not satisfactory that perception of customer (service received and felt by customer) is not according to customer expectation. The ability and competence of employees in providing services to customers is not satisfactory especially in explanation about the products offered by BPRS. This is because not all employees understand all the products offered by BPRS.
- Customer's assessment of Reliability dimension is not satisfactory ie customer perception (service received and perceived by customer) is not in line with the customer's expectation. The ability of employees in providing services quickly and accurately is not in line with customer expectations. Unavailability of special security guards to guard customers when carrying large amounts of money is not in the time frame as promised.

- Customer's assessment of Tangibles dimensions is satisfactory where perceptions (service received and perceived) match customer expectations. While the customer assessment of the comfortable and air-conditioned office and lounge reveals that the availability of special rooms for special customers the availability of free drinks are in line with customer expectations.

- Customer assessment of the Empaty dimension is not satisfactory where the customer's perception (the service received and perceived) is not in line with the customer's expectations. The evident from the customer assessment reveals that the bank guarantees the confidentiality of the customers the ease of procedure for financing and the profit sharing should be attractive and in accordance with the agreement. In particular it is easy to apply financing procedures where not all SMEs can make bookkeeping while the financial statements are a requirement in applying for financing

- Customer's assessment of the Responsiveness dimension is not satisfactory where the perception (service received and perceived) is not in accordance with the wishes of the customer as it is seen from the customer assessment that the way employee / employee serves customers in Islam employees / employees willing to help customer difficulties and services are Fast and efficient yet fulfill the customers' expectation especially the services provided by BPRS has not been fast and efficient because it is related to the rules given by BI.

From the six dimensions of quality of CARTER the order of service quality dimension that must be improved is first order which is improved first is the Compliance dimension where customer expectation about BPRS Jabal Nur fully implement syaria system of Islam has not been fulfilled as showed from Gap between perception and customer expectation ranks that is the highest. The second order to improve the quality of service is assurance that the ability and skill of employees of BPRS Jabal Nur especially the Custumer Service must master all products offered. The third order is Responsiveness that is speed and responsiveness in providing services. Fourth order is Empaty where employees can understand customers' needs. The fifth order of Realibility is the ability to provide services promptly accurately and satisfactorily. While Tangible dimension is physical appearance where it is good and has satisfied the customers . 


\section{CONCLUSION}

- The six dimensions of CARTER quality, the five dimensions of Compliance Assurance Reliability Empaty and Responsiveness of service received by customers are not satisfactory.

- Only Tangible quality dimensions that satisfy, there are physical appearance and equipment including air-conditioned and comfortable waiting room special rooms available for special customers and free drinks.

- Quality of Service BPRS has not been satisfied customers except tangible, this is in accordance with Rofikul Islam research that have services quality research of Bank Islam in Malaysia where the quality of service has not met the expectations of customers.

\section{References}

[1] Asma Abdul Rehman, (2012) "Customer satisfaction and service quality in Islamic banking: A comparative study in Pakistan, United Arab Emirates and United Kingdom", Qualitative Research in Financial Markets Vol. 4 Issue: 2/3,pp. 165-175

[2] Beni Ahmad Saebani, 2008, Metode penelitian, Pustaka Setia, Bandung

[3] Erlane K Ghani, Jamaliah Said, Carter Instrument for Zakat Organization an Examination Using Dhelpi Technique, Research Journal of International Studies Issue 21 , Oktober 2011, page 138-144

[4] Karyadi Mintaroem, 2004, Service Quality and Customer satisfaction on Islamic Bank in Surabaya,International ournal Ihya „Ulum
al-Din, Volume 6 no 2 Desember 2004 hal $139-158$

[5] Makhalul Ilmi SM, 2002, Teori dan Praktek Mikro Keuangan Syariah, UII press, Yogyakarta

[6] Muhamad Ridwan, 2006, Sistem dan Prosedur Pendirian Baitul Mal wat-Tamwil (BMT), CitraMedia , Yogyakarta

[7] Muslim Amin, Zaidi Isa, (2008) "An examination of the relationship between service quality perception and customer satisfaction: A SEM approach towards Malaysian Islamic banking", InternationalJournal of Islamic and Middle Eastern Finance and Management, Vol. 1 Issue: 3,pp. 191-209

[8] Nursya ${ }^{e e} b a n i$ Purnama, 2006, Manajemen Kualitas, Ekonisia, Yogyakarta

[9] Rafikul Islam, Selim Ahmed, Dzuljastri Abdul Razak, (2015) "Identifying the gaps between customer expectationsand perceptions on service quality dimensions of Islamic banks in Malaysia", International Journal of Quality and Service Sciences, Vol. 7 Issue: 4, pp.424-441

[10] Sharil Shafie, Dr Wan Nursofiza Wan Azmi, Profesor Sudin Harun, 2004, Adopting and Measuring Customer Service Quality in Islamic Bank: A Case Study of Bank Islam Malaysia Berhad, Jurnal of Muamalat and Islamic Finance Research 2004 Volume 1

[11] Suharsimi Arikunto, 2010, Prosedur Penelitian, PT Rineka Cipta, Jakarta

[12] Tony Wijaya, 2011, Manajemen Kualitas Jasa, PT Indeks, Jakarta 